\title{
DIFFICULTIES OF DIABETIC PATIENTS IN THE ILLNESS CONTROL: FEELINGS AND BEHAVIORS
}

\author{
Denise Siqueira Péres ${ }^{1}$ \\ Manoel Antônio dos Santos \\ Maria Lúcia Zanetti ${ }^{3}$ \\ Antônio Augusto Ferronato 4
}

Péres DS, Santos MA, Zanetti ML, Ferronato AA. Difficulties of diabetic patients in the illness control: feelings and behaviors. Rev Latino-am Enfermagem 2007 novembro-dezembro; 15(6):1105-12.

This study aimed to identify difficulties diabetic patients face during treatment in controlling the disease. A total of 24 diabetic patients, attended in the Nurse Educational Center for Adults and Elders in 2003, participated in the study. The data was collected individually, through a written report guided by a question previously elaborated, on a pre-scheduled date. The Content Analysis technique was used in the data analysis. The results showed several difficulties related to the treatment follow up: rejection and denial of the patient's condition, suffering and revolt due to restrictions imposed by the diet, physical activity and medication. It is possible to infer that the focus of the education approach should not be restricted to the transmission of knowledge; it should also include emotional, social and cultural aspects that also influence in the treatment follow up.

DESCRIPTORS: diabetes mellitus; health education; chronic disease

\section{DIFICULTADES DE LOS PACIENTES DIABÉTICOS PARA EL CONTROL DE LA ENFERMEDAD: SENTIMIENTOS Y COMPORTAMIENTOS}

Este estudio tuvo como objetivo identificar las dificultades de los pacientes diabéticos en relación al tratamiento para el control de la enfermedad. Participaron 24 diabéticos acompañados en el Centro Educativo de Enfermería para Adultos y Ancianos en 2003. Para obtener los datos, se utilizó un relato escrito, de forma individual, en día predeterminado, a partir de una pregunta orientadora previamente elaborada. En el análisis de los datos se utilizó la técnica de Análisis de Contenido. Los resultados mostraron que son innumeras las dificultades relacionadas al seguimiento del tratamiento: rechazo y negación de la condición de enfermo, sufrimiento y revuelta debido a las restricciones impuestas por la alimentación, actividad física y medicamentos. Es posible inferir que el enfoque de la aproximación educativa no debe restringirse apenas a la transmisión de conocimientos; también es importante que englobe aspectos emocionales, sociales y culturales que influencian en el seguimiento del tratamiento.

DESCRIPTORES: diabetes mellitus; educación en salud; enfermedad crónica

\section{DIFICULDADES DOS PACIENTES DIABÉTICOS PARA O CONTROLE DA DOENÇA: SENTIMENTOS E COMPORTAMENTOS}

Este estudo teve como objetivo identificar as dificuldades dos pacientes diabéticos em relação ao tratamento para o controle da doença. Participaram 24 diabéticos acompanhados no Centro Educativo de Enfermagem para Adultos e Idosos, em 2003. Para obtenção dos dados utilizou-se de relato escrito, de forma individual, em dia pré-determinado, a partir de uma questão norteadora previamente elaborada. Na análise dos dados, utilizou-se a técnica de análise de conteúdo. Os resultados mostraram que são inúmeras as dificuldades relacionadas ao seguimento do tratamento: rejeição e negação da condição de doente, sofrimento e revolta devido às restrições impostas pela alimentação, atividade física e medicamento. É possível inferir que o enfoque da abordagem educativa não deve se restringir apenas à transmissão de conhecimentos, mas é importante englobar os aspectos emocionais, sociais e culturais que influenciam no seguimento do tratamento.

DESCRITORES: diabetes mellitus; educação em saúde; doença crônica

${ }^{1}$ Psychologist, MS in Medical Sciences, e-mail: desiperes@ig.com.br; ${ }^{2}$ PhD Professor, University of São Paulo at Ribeirão Preto, Faculty of Philosophy, Siences and Letters, Brazil; ${ }^{3}$ Associated professor, University of São Paulo at Ribeirão Preto, College of Nursing, WHO Collaborating Center for Nursing Research Development, Brazil; ${ }^{4}$ Psychologist 


\section{INTRODUCTION}

Currently, diabetes mellitus is considered one of the most important Public Health problems, because of the number of people affected, disabilities and premature mortality it causes, as well as because of the costs involved in the control and treatment of its complications. These factors justify the development of studies not only to detect but also to further an educative and therapeutic intervention process in the diverse stages of this disease and its complications.

One of the biggest problems health professionals meet in the intervention process with diabetics is low treatment adherence, a recurrent phenomenon in the treatment of diseases that demand changes in life habits. Stimulating treatment adherence is extremely important and education in health can be considered one of the strategies that stimulate better patient adherence to the treatment scheme ${ }^{(1)}$. In this context, education in health has been considered an integral part of the treatment of chronic diseases ${ }^{(2)}$. However, many educational programs in health fail because they do not take into account the psychological, cultural, social, interpersonal aspects and the real psychological needs of the diabetic person ${ }^{(3)}$.

The focus of an educative approach must involve the subjective and emotional aspects that influence treatment adherence, going beyond cognitive processes $^{(4)}$. Thus, it is essential for health education to consider the patients' reality and experience, because information in health is oftentimes vertically provided, not allowing patients to have further participation and not considering what they already know or what they would like to know. With this in mind, the goal is to transform subjects who assume a passive attitude towards their treatment into participative individuals.

It seems to be necessary to acquire deeper knowledge and understanding of the patient's experiences, because the diabetic patient "attributes to the experiences (s)he had with the disease not only a meaning, but a meaning that relates with his(er) way of existing"(5). Therefore, an effective education process requires knowing about the patients' beliefs, feelings, thoughts, attitudes and behaviors, so that the subjects learn from their environment ${ }^{(6-7)}$ and from their relations with other individuals.

Knowing what patients learn from their reality and how they organize their routine can provide insights in order to establish interventionist strategies, besides providing subsidies that can improve the comprehension of factors associated to treatment adherence ${ }^{(7)}$. It is necessary to understand how a person with diabetes perceives him(er)self and experiences a world of limitations, that is, the diabetic person as an integral being, capable of comprehension, affectivity and action, inside his(er) own perspective of the world.

It is important to appoint that the disease diagnosis frequently causes an emotional shock for a person who is not prepared to live with limitations caused by a chronic disease. Thus, the diabetes experience breaks the organic harmony and, many times, transcends the person him(er)self, interfering in the family and community life, affecting the patient's universe of relations. Having to change consolidated life habits and assume a routine that involves rigorous discipline of diet planning, incorporating or increasing physical activity and the permanent and continuous use of medication, impose the need to get in touch with feelings, desires, beliefs and attitudes. A modified life style is not magically implemented, but happens along a path that involves rethinking one's life project and expectations for the future.

Therefore, changes in life habits are part of a slow and difficult process, especially in terms of food. Eating habits are related to at least three complex factors: cultural, which are transmitted from generation to generation or by social institutions; economic, which refers to the cost and availability of food; and finally, social, which is related to the acceptation or rejection of certain eating patterns. Other factors influence the individual, leading to the adoption, oftentimes, of inappropriate behavioral patterns, such as aversion to certain foods, beliefs related to supposed dangerous actions and taboos or prohibition to use or consume certain products ${ }^{(8)}$.

The main difficulties regarding adherence to medication therapy are related to the number of medications used by diabetic patients, who usually present comorbidities; to the medications' adverse affects and high cost; to myths and beliefs; to the patients' instruction level, which can limit access to information and comprehension; to the disease's asymptomatic character, which most of the time makes patients not acknowledge the importance of the medication treatment ${ }^{(8)}$.

Despite efforts to make diabetic patients follow the diet, physical activity and medication 
therapy, it has been observed that treatment adherence is low. In this sense, there is a need to understand how psychological aspects - feelings and behaviors - interfere in the motivation and willingness to incorporate changes into their routine, which would allow them to live better with the disease.

This study is justified by the fact that getting to know diabetic patients' feelings and behaviors can support the adoption of more effective intervention strategies in diabetes control.

\section{METHODOLOGY}

This is an exploratory descriptive study, carried out at the Nursing Education Center for Adults and Elderly - CEEAI, located on the Ribeirão Preto campus of the University of São Paulo. Every Tuesday from 2 to 5 PM, multidisciplinary work is performed at this center, involving professionals from different specialties, such as: nurses, nutritionists, psychologists and a physical educator. The sample of 24 diabetics was selected by convenience. The majority was female, age between 25 and 76 years old, literate, with eight years of schooling, from Ribeirão Preto, who perform household activities. Regarding the place of treatment, the majority had their health follow-up at Basic Health Units and a large part of them reported type 2 diabetes. The majority reported other diseases besides diabetes, such as: arterial hypertension, hypothyroidism, osteoporosis, cardiopathy, labyrinthitis, gastritis, dyslipidemias and circulatory problems.

A guiding question was elaborated for data collection: "What are the difficulties you have met in the follow-up of diabetes treatment?" The data were colleted in February 2003 after the individual signing of the Free and Informed Consent Term. Patients were instructed to consider the difficulties and feelings related to eating habits, medication, physical activity and other factors that interfere in diabetes control. The average time to write the reports was 60 minutes.

Qualitative data analysis was chosen because it permits greater understanding of the phenomena's multidimensional character and also the capturing the experience's different meanings, which helps in the comprehension of the individual and his(er) context. The data were analyzed through the content analysis technique ${ }^{(9)}$.

\section{RESULTS AND DISCUSSION}

Data analysis involved three analytical categories, related to: eating habits, physical activity and medication. Next, the description and analysis of the categories elaborated from the diabetics' reports are presented.

Table 1 presents the analytical categories of the respondents regarding eating habits. The answers obtained fitted in the following categories: difficulty in controlling impulses $(n=9)$, difficulty in following the diet $(n=7)$. On the other hand, less respondents reported having no difficulties in following the diet $(n=4)$ or being able to control the diet well $(n=1)$.

Table 1 - Distribution of analytical categories regarding eating habits, reported by the diabetic patients attended at the CEEAI. Ribeirão Preto/SP, Brazil. 2006

\begin{tabular}{ll}
\hline \multicolumn{1}{c}{ Analytical categories } & \multicolumn{1}{c}{ Respondents } \\
\hline Difficulty in controlling impulses & $1,8,9,10,11,12,15,20,22$ \\
Difficulty in following the diet & $6,7,9,16,17,23,24$ \\
No difficulty in following the diet & $2,3,4,14,18$ \\
Reactions and negative feelings & \\
- preoccupation/anxiety & 16,22 \\
- mad at the world, difficulty in reasoning, & 13 \\
psychological discomfort and denial & \\
- discouragement & 16 \\
- privation of pleasure & 23 \\
- vulnerable to critiques & 24 \\
Did not answer & $5,12,19,21$ \\
\hline
\end{tabular}

Some reports show feelings aroused by the need to impose rigorous diet control. Some intense emotional reactions also emerged, such as: "mad at the world", difficulties to rationalize, psychological discomfort, preoccupation and anxiety, feelings of discouragement, privation of pleasure, susceptibility to critique and denial. The patients appointed great difficulty in controlling impulses, according to the reports below:

I have a hard time because I like to eat well. And there are many things I can't eat. I like and can't avoid eating (S10)

Regarding the diet, I try to fight so as not to eat certain foods, but sometimes I can't help myself (S20)

The difficulty in following the prescribed diet happens because it is related to acquired habits, to a defined time schedule, to the cultural value of food, to socioeconomic conditions and the psychological issue involved. The transgression and desire to eat are always present in the diabetic patient's life. "The desire to eat makes one suffer, restrain, salivate, 
forget, transgress, lie, deny, admit, feel pleasure, control and feel guilty" ${ }^{(10)}$.

One respondent reports that her difficulty consists in preparing food for the family, going to parties and not being allowed to eat: to look, manipulate, prepare food instigates the desire, as follows:

My difficulty is the diet, it is making things for the kids and not being allowed to eat, going to a party and just look and say: 'thanks, I can't'... (S8)

There is a need to keep the oral impulses under control but, simultaneously, there is difficulty in keeping the prescribed diet for a prolonged period - suddenly you lose control and episodes of compulsive eating occur, which provide a temporary relief by liberating voracity. The mechanism of denial is not enough to contain negative feelings (anger), mobilized by the awareness of losing control of one's impulsivity. These feelings overcome the rational control, leading to difficulty to concentrate and rationalize. The influence of emotions in the eating habits is represented in the reports:

I don't always manage, I know it is dangerous, I try to control, but when I get anxious or upset, I go and get something to eat. I eat to calm down my emotions. For a few days, I'm able to control myself, doing what is right, eating right, but an emotion, a nuisance is enough to make me lose it (...) my biggest problem is food and I would very much like some help in this sense (S22)

These last two reports clearly show how much some diabetic people recognize the influence of emotions in their difficulties to control the diet. The act of eating is one of the most complex human behaviors, since it does not only mean the intake of nutrients, but it also involves a large range of emotions and feelings, besides the cultural meanings attributed to food. In this context, one symbolically eats emotional tension, anxiety and unemployment. Thus, the behavior regarding food is related to both technical and objective aspects - what we eat, when and where we eat, with whom we share the food - as well as with sociocultural and psychological aspects ${ }^{(11)}$.

In the report described above, it is also noted that, besides the voluntary effort needed to keep discipline and control, the food searched serves to placate the anxiety aroused by the period in which one manages to keep the diet. In this sense, it can be said that, many times, privation rimes with compulsion.

The participants' reports, who highlighted their difficulties in following the prescribed diet, varied from simple disappointment with these difficulties to detailed reports that allow us a deeper comprehension of the bottlenecks faced, according to the reports below:

This is a little hard. I haven't had much appetite for food. I prepare it for others and don't care much about me. As I haven't been feeling well because I have not followed a regulated diet, I get concerned and now I am trying to go back to a regular $\operatorname{diet}(\mathrm{S} 16)$

Being exposed to other people's critique and relatives' non acceptance makes diabetics feel "different" from others. "Being different" is a harsh experience. The difference is treated as something problematic and not as a peculiarity that singularizes the subject, that is, a difference that makes difference as it is the base itself of the personal identity, according to the report below:

The diet is the most difficult part, because the family habits are the opposite of the diet (pasta, fried food and sweets). Many times people don't understand that it is not a desire to be different, but a need. There is always someone criticizing why the sugarless coffee, juice etc, especially my mom, I feel she doesn't accept this change (S24)

Food control is understood in the perspective of privation, "diet", prohibitions and restrictions imposed on oral gratification and not to the need of reeducating eating habits. The prevalent beliefs emphasize restriction, highlight the "cannot" to the detriment of other possibilities, such as gains in quality of life, provided that the diabetic person follows the recommendations prescribed by professionals.

On the other hand, there are reports that do not mention difficulty in following the diet:

I don't have a hard time in keeping my blood glucose under control because I don't use medication, I control it only by restricting the quantity of food, I mean, reeducating my previous eating habits, selecting foods and fruits (S18)

These reports indicate that a part of the diabetics who attend the study site is capable of following a food reeducation plan. The others, although they acknowledge the importance of reeducating their eating habits in order to maintain blood glucose control and prevent complications, report not being able to adequately deal with the diet limitations. There is a significant gap between the recommended ideal eating plan and what is possible in practice.

Table 2 shows the analytical categories elaborated from the reports according to medication use. The obtained answers were included in the categories: insulin, $(n=7)$ and oral antidiabetics 
$(n=14)$, besides other answers $(n=3)$. Regarding insulin, the following subcategories were obtained: difficulty in taking insulin $(n=5)$, refusal to taking insulin $(n=1)$ and no difficulty in taking insulin $(n=1)$. Regarding oral antidiabetics, the following subcategories were found: doubts regarding the time schedule $(n=4)$, forget to take the medication $(n=4)$, no difficulties in taking medication $(n=4)$, difficulty in taking medication $(\mathrm{n}=2)$ and refusal to take medication $(n=1)$.

Table 2 - Distribution of the analytical categories regarding medication use referred by the diabetic patients attended at the CEEAL. Ribeirão Preto/SP, Brazil 2006

\begin{tabular}{ll}
\hline \multicolumn{1}{c}{ Analytical Categories } & \multicolumn{1}{c}{ Respondents } \\
\hline Insulin & $2,10,13,14,15$ \\
- difficulty in taking & 1 \\
- refusal to take & 23 \\
- no difficulty with medication & \\
Oral antidiabetics & $3,4,16,24$ \\
- doubts regarding time schedule & $7,11,20,24$ \\
- forget to take medication & $1,2,12,21$ \\
- no difficulty with medication & 13,17 \\
- difficulty in taking & 9 \\
- refusal to take & \\
Other responses & 19 \\
- difficulty to sleep & 13 \\
- bad mood & 22 \\
- other medications & 18 \\
- did not answer &
\end{tabular}

It is observed in general that 16 of the 24 respondents present difficulty regarding medication use, whether because of "doubts" regarding the correct way to use it or due to blunt "refusal" or alleged "forgetfulness".

Several reports mentioned below refer to the difficulty in taking insulin, while "forgetfulness" is the most frequent: the patient simply forgets taking it in the prescribed schedule. Some feelings aroused by the daily use of insulin are: "hatred", "terror" and "bad mood". At the same time as daily insulin use keeps control of the diabetes, it also denounces that one needs to take it in order to be healthy.

Difficulty in taking insulin, I take medication, but sometimes I forget the correct time (S2).

Medication, I get terrified at the insulin time (...) I'm a bad humored person (S13)

The report above shows the refusal to take insulin. Another study also found that the majority of patients have difficulty to accept insulin use because it is "considered an aggression to the body; something that causes dependency (to the organism and on other people) and loss of self control; imposes limits to activities (work and leisure); causes concerns regarding dose preciseness; causes discrimination; is boring and uncomfortable" (12).

I take medication, but the doctor always wants me to take insulin, but I don't want to (S1)

Only one report showed acceptance to take insulin:

For me it is not difficult to take medication, I take insulin twice a day (23)

Some reports showed doubts regarding the schedule for taking oral antidiabetics, such as:

I have difficulties regarding me"dication at lunch time. I take Daonil, fifteen minutes before lunch, then I have to take Glifage after lunch, I don't know if it is right after lunch or if I have to wait half an hour to take it (S3)

The following report shows the importance of receiving orientation and information. Having access to information is undoubtedly very important, but it is not the only aspect involved in the complex relation between knowing and doing(13). It is difficult to translate knowledge into attitude:

Medication: this has been my biggest problem in this current phase. I take medication for blood pressure, circulation, diabetes, vitamins. I used to mix up the time of each, but today, thanks to orientation, I'm overcoming this stage. The need to be correctly medicated and physically and emotionally well will reflect in the evolution or good maintenance of one's body and mind, so that one can live with this disease (S16).

Several patients described themselves as "forgetful" or "distracted" when they do not take the prescribed medication. A patient can get tired of living with a chronic disease. It can be said that constant medication use somehow highlights the presence of the disease ${ }^{(14)}$. That is, "the fact of taking medication reminds one's chronic health condition, potentially causing anxiety, fear and sadness, which make us avoid this situation" ${ }^{(15)}$, as follows:

Medication: at first I didn't forget to take medication at the right time, which is happening nowadays, not very frequently, but sometimes I only realize I didn't take it at the next meal (S24)

Some patients did not consider frequent medication use as difficult:

I don't think medication is difficult (S12).

On the other hand, there are difficulties in taking medication. 
(...) the pills still make me sick. I'm a bad humored person (S13).

Table 3 presents the categories elaborated from the diabetics' reports regarding physical activity. The answers obtained fitted in the following categories: does not practice physical activity $(n=6)$, practices but not daily $(n=4)$, practices physical activity $(n=6)$; eight did not answer.

Table 3- Distribution of analytical categories regarding physical activity referred by diabetic patients attended at the CEEAI. Ribeirão Preto/SP, Brazil 2006

\begin{tabular}{ll}
\hline \multicolumn{1}{c}{ Analytical categories } & \multicolumn{1}{c}{ Respondents } \\
\hline No physical exercise & $1,11,12,13,14,16$ \\
Practice, but not daily & $3,4,17,24$ \\
Practice physical exercise & $2,7,18,20,22,23$ \\
Did not answer & $5,6,8,10,15,19,21$ \\
\hline
\end{tabular}

There is always a justification for the non practice of physical exercises: "Not walking (...) is justified and attributed to an important reason" (10). The discourse of patients who do not practice any kind of physical activity included the following reasons:

I don't do anything because my legs hurt (S1).

I don't do activities, get too tired. Nor walking (S14).

On the other hand, physical activity was also seen as something pleasurable, capable of controlling blood glucose and weight. Regarding patients who practice physical activity:

By walking I can keep my blood glucose level and decrease my weight (S18).

Some patients report the practice of physical activity, but not systematically. The justifications for non practice are: travel, work, stress and changes in the weather.

It is difficult when I travel (S17).

Not always. Because of my work it moves to the background, especially when I'm stressed or a little disheartened with life. I know I need to increase it, or better yet, practice other physical activities. When it rains, then, I literally don't walk (S24)

Table 4 presents the diabetics' analytical categories regarding feelings associated to the experience of the disease. Results indicate that they articulate around multiple cores of meanings, whose axes point to strongly contrasting characteristics.

Thus, negative feelings, such as anger, revolt, sorrow and frustration, coexist with amicable or pleasurable feelings like satisfaction, well-being and gratitude.
Table 4 - Distribution of analytical categories referred by diabetic patients attended at the CEEAI, according to feelings associated to the disease. Ribeirão Preto/ SP Brazil, 2006

\begin{tabular}{ll}
\hline \multicolumn{1}{c}{ Analytical categories } & \multicolumn{1}{c}{ Respondents } \\
\hline Anger / revolt / sorrow / resistance / the norld is over & $10,11,16,17,20$ \\
Satisfaction / well-being / happiness / gratitude & $17,18,20,21$ \\
Restriction / privation / imposition & $1,7,22$ \\
Identity. the "diabetic being" & $1,9,12$ \\
Treatment as an averting situation & $1,10,11$ \\
Frustration & 7,14 \\
Non acceptance of diabetes & 13,17 \\
Ambivalence, conflict (impotence versus hope) & 21,22 \\
Anxiety / preoccupation / suffering & 24,13 \\
Respect to the disease, acceptance in the current moment 16,17 \\
Personal responsibility & 17,24 \\
Lack of control & 16 \\
Discouragement & 13 \\
Guilt & 7 \\
\hline
\end{tabular}

It can be hypothesized that feelings that favor greater proximity with the consequences in the diabetic person's daily life can also facilitate the acquisition of abilities and attitudes that increase treatment adherence. Likewise, in the opposite sense, negative feelings aroused by a prolonged experience of the limitations imposed by a chronic disease could favor the distancing of what evokes the disease or treatment. In that case, a distancing attitude in relation to one's own emotions, experienced as hostile, unbearable and potentially disruptive would predominate, because they involve a high level of psychic suffering.

It is understood this way because the ambivalence in experiencing the disease itself is a characteristic of many diabetic patients. Beside feelings of anger and revolt, due to restrictions and privations required to maintain the disease under control, there are emotions linked to happiness, personal responsibility and a certain respect regarding the disease. Thus, the diabetic identity is molded in a complex process that demands getting in touch with potentially disaggregating emotions, generated by the daily struggle with the interdiction (the proverbial "can not") and by rejection of the special condition, which makes the patient feel different from others and, consequently, less normal. This conflict with oneself one's possibilities and impossibilities - leads to intense emotional reactions: sorrow, anxiety, permanent preoccupation, eternal surveillance to control one's impulse and the desire to trespass the limits and lose control - after all, the fear of lack of control is also a constant feeling in diabetes patients. 
The difficulty to accept this condition makes the patient live an endless dilemma. Accepting oneself as diabetic requires the perception of someone who learned somehow to live with the bother, discomfort and pain caused by the restriction and containment of habits, by the control imposed by the treatment on one of the most basic human impulses, which is orality. The meaning of self care implies acknowledging oneself as carrying an important limitation, determined by a chronic disease. Therefore, it implies a loss of autonomy:

My biggest feeling is being diabetic. Having to take medication every day, not being able to eat tasty food (S1)

Intolerance to frustration impedes the patient from seeing (him)herself in a different way and therefore, elaborating another version of (him)herself , making another description of the self that would permit to define him(er) as a being with possibilities, and not only limitations. How to assume a new identity if it brings what is rejected: renouncing pleasure, selfdiscipline, permanent responsibility regarding one's own life and self-care practices?

Nowadays, with the guidance received at the Diabetes Education Center, practicing daily exercises and taking the medication prescribed by the doctor, I feel very well. Only now do I realize that I am the one who takes good care of myself (S17).

In addition, the experience of getting sick is extremely peculiar in diabetes because of its insidious process. Sometimes, the awareness of loss of the "healthy individual" condition is acquired too late, after the occurrence of complications caused by poor blood glucose control.

I never cared about the disease until my mom had several complications because of the kidney disease... she had her legs amputated, then I started to get more concerned... (S10)

That is why it is understandable that patients alternate between moments of impotence, discouragement and moments of greater confidence in the treatment. These oscillations can be seen as a reflection of what happens in one's life: sometimes one's relation with life is depreciated by the belief that life is unfair, sometimes it is reinvigorated by the belief that life is worthy even with limitations, assuming responsibility for one's own destiny and one's choices. That is why the renovation of hope in life seems to be an essential requirement to be pursued by diabetes patient care. Generally, they are individuals who have gone through successive treatments, who were submitted to innumerous previous attempts and had no success, and who were treated by several professionals, making it difficult to maintain ties. The possible previous experiences of failure arouse feelings of persecutory instead of reparatory guilt:

I feel sorry for having discovered diabetes too late. When I started to gain too much weight, I didn't go to a doctor, even having great hunger and pain all over the body (S14)

Relating with the disease in a more frank way means facing one's finitude and restriction to live the world's precious aspects, hindering or impeding the diabetic from keeping a pleasurable relation with life. Disappointment and frustration are constant:

Feelings: when there is a place to go and I can't, I feel really hurt... (S7)

The incapacity of elaborating the anxiety and constant concern cause feelings of anger, making the patient assume attitudes of great revolt and rebellion in view of the treatment:

Too much sorrow, because I don't like to do the treatment (S11)

An attitude of denial predominates in several reports:

I have been diabetic for 13 years now and still don't accept it. I suffer a lot. I am a very bad humored person (S13).

Diabetes patients constantly seek meanings for their condition, which permit to construct this diabetic being. Depending on the meanings they are able to construct and the position adopted regarding the disease, the closer they will get to a genuine acceptance of their condition, assuming a social identity of subject of the disease and a more responsible attitude in view of its controls. Acquiring respect for the disease is a slow, suffered process, permeated by mood swings (discouragement, sadness, conflicts, guilt) and feelings of impotency, which can generate feelings of helplessness and worthlessness. When depressive meanings-feelings predominate, the perception of control on significant events in life and self-efficacy - that is, the feeling of being competent in carrying out daily tasks - can be compromised, which in turn contributes to low selfesteem.

\section{FINAL CONSIDERATIONS}

During treatment, diabetic persons experience feelings and behaviors that hinder the acceptance of the chronic health condition and 
consequently, the adoption of healthy habits that would allow them to deal with limitations caused by the illness.

The categories related to eating, medication, physical activity and feelings associated to the disease are structured around feelings and behaviors that work as guiding suppositions in the particular way each patient appropriates him(er)self of his/her own disease. In other words, the way one expresses one's feelings directs one's behavior related to health, in the search for healthy and unhealthy habits, determining possibilities and difficulties/limitations for the control of diabetes.

We believe that a better understanding of the diabetic person's feelings and behaviors can contribute to re-dimension the healthcare model directed to this clientele, incorporating premises of integral care that include dimensions of biological, psychological, social and spiritual well-being, among others recommended by the primary health care model.

\section{REFERENCES}

1. Rabelo SE, Padilha MJCS. A qualidade de vida e cliente diabético: um desafio para cliente e enfermeira. Texto Contexto Enfermagem 1999 setembro/dezembro; 8(3):25062.

2. Almeida HGG, Takahashi OC, Haddad MCL, Guariente MHDM, Oliveira ML. Avaliação dos conhecimentos teóricos dos diabéticos de um programa interdisciplinar. Rev Latinoam Enfermagem 1995 julho; 3(2):145-64.

3. Zanetti ML, Mendes IAC. Tendência do locus de controle de pessoas diabéticas. Rev Esc Enfermagem USP 1993 agosto; $27(2): 246-62$.

4. Ferraz $A M$, Zanetti $M L$, Brandão $E C M$, Lídia $C R$, Milton $C F$, Glória MGFP, Francisco JAP, Leonor MFBG, Renan MJ. Atendimento multiprofissional ao paciente com diabetes mellitus no ambulatório de diabetes do HCFMRP-USP. Medicina 2000 abril-junho; 33:170-75.

5. Damasceno MMC. O existir do diabético: da fenomenologia à enfermagem. Fortaleza: Fundação Cearense de Pesquisa e Cultura, 1997.

6. Sawaia BB. Análise psicossocial do processo saúdedoença. Rev Esc Enfermagem USP 1994 abril; 28(1):10510 .

7. Cade NV. O processo psicossocial faz a diferença na compreensão e na educação para a saúde de pessoas com doenças crônicas. Cogitare Enfermagem 1998 janeiro-junho; 3(1):57-60.

8. Zanetti ML, Otero LM, Freitas MCF, Santos MA, Guimarães FPM, Couri CEB, Péres DS, Ferronato AA, Dal Sasso $K$, Barbieri AS. Atendimento ao paciente diabético utilizando o protocolo Staged Diabetes Management: relato de experiência. RBPS 2006; 19(4):253-60.

9. Minayo MCS. Pesquisa social: teoria, método e criatividade. Petrópolis (RJ):Vozes; 1996.

10. Santana MG. O corpo do ser diabético, significados e subjetividade. [Tese]. Florianópolis: Centro de Ciências da Saúde/UFSC; 1998.

11. Garcia RWD. Representações sociais da alimentação e saúde e suas repercussões no comportamento alimentar. PHYSIS: Rev Saúde Coletiva 1997; 7(2):51-68.
12. Silva DMGV. Narrativas do viver com diabetes mellitus: experiências pessoais e culturais. [Tese]. Florianópolis: Departamento de Enfermagem/EFSC; 2000.

13. Santos ECB, Zanetti ML, Otero LM, Santos MA. O cuidado sob a ótica do paciente diabético e de seu principal cuidador. Rev Latino-am Enfermagem 2005 maio-junho; 13(3):397406.

14. Pinkus L. Psicologia do doente. São Paulo (SP): Paulinas; 1988.

15. Peres DS, Magna JM, Viana LA. O portador de hipertensão arterial: atitudes, crenças, percepções, pensamentos e práticas. Rev Saúde Pública 2003; 5(37):635-42. 